\title{
コンクリートブロック塀等の調 CHARACTERIZATION OF THE 查に基づく仙台市内指定避難所 DEFECTIVE MASONRY WALL 周辺道路の状態評価 \\ EXISTED STREETS THAT EXTENDED AROUND THE REFUSE AREAS IN SENDAI-CITY
}

\begin{abstract}
Masayoshi SAICHI — $* 1$
Refuse areas designated by Sendai-city were established in terms of the safety concept with evaluating the situation of existing masonry walls. A methodology associated with the binominal distribution was presented as a parametric model. The safety ranking for existing masonry walls established by the residential section of city office was devoted for the statistical analysis. The result of the inspection indicated a feature that the distributed pattern of the suspicious refuse areas could be related with the urbanizaiton.
\end{abstract}

1. はじめに

規模の大きな地震の発生の際には、ブロック塀（補強コンクリー トブロック造の塀）や石塀、門柱などの外構施設が転倒、あるいは 脱落し（以後、それらを総称して「倒壊」と表記）、人的な被害を 引き起こす場合がある。最近では 2005 年 3 月の福岡県西方沖地震 （M7.0）において、死亡者（1 名：転倒ブロック塀による）が出て いる。

1978 年 6 月の宮城県沖地震（M7.4）では、被災による死亡者 28 名のうち、16 名が外構施設の倒壊によるものであった (ブロック塀 9 名、石塀 5 名、門柱 2 名）ことから、地震時の外構施設の倒壊に ついて、その危険性が広く知られるようになった ${ }^{1)}$

行政機関としての仙台市は、1978 年宮城県沖地震の被災を一つの 教訓として、同地震の直後より、ブロック塀や石塀など、組積造の 塀（以後、「ブロック塀等」と表記）の実態調查をたびたび実施し 2)、特に 1996 年からの 8 年間は、市内にある指定避難所の周辺を主 な対象として、調査を継続的に行なった ${ }^{3)}$ 。この調査（以後、時に 「仙台市調查」と表記）は「各種台帳の作成と築造状態の所有者へ の通知」という目的に合わせて、担当部局（仙台市都市整備局）の 吏員による計画・立案を経て実施されたものであった。同調査を通 して蓄積された計画、実施、評価をはじめとする様々な技術的情報 は、一つのシステムとして確立され、さらにモデルケースとなって、 他の行政機関（県や市町村）へも伝わっている。その後、行政機関 のネットワークを介した広がりによって、他県においても、同様の やり方による調查が行なわれる例が出てきている。

実態調査の実施から、その結果に基づいた行政指導へとつながる 一連の流れは、すでに赛績のあるシステムとなっており、調査方法
の妥当性についても、一定の評価はできるものと考えられている4)。 実際、仙台市では同調查の結果をもとに、危険と思われるブロック 塀等の所有者を対象として、改修や撤去に向けた行政指導を実施し ており、その際に調查結果が活用されている。ただし、その利用と しては、所有者個人に対する行政指導の技術的な根拠としての、言 わば、個別的な利用に留まっており、例えば、地域のような一定の 広がりをもった領域を対象として、ブロック塀等の倒壊色険性や道 路の安全性を評価するような活用の仕方はされていない。

今般、仙台市の協力により、調查データの一部（個人情報に関わ る部分を除いたもの）の提供を受けると共に、同調查の関連資料を 分析する機会を得た。そこで、同調查で得られたデータの更なる活 用を図る観点から、市域の中に存在している指定避難所に焦点を当 て、避難所周辺の「倒壊危険性を内在するブロック塀等」の分布状 況を捉えると共に、一定の広がり（避難所から半径 $500 \mathrm{~m}$ の範囲）を もった領域を単位として、ブロック垪等の危険度、あるいは避難所 周辺道路の状態を評価することを試みた。これにより、例えば、行 政として優先的に指導を行なってゆくべき市内の地域を特定したり、 当該地域に居住する住民全体に対する注意喚起につなげたりするこ とが可能となり、さらには、行政が進めている不良ブロック塀等の 除去の促進に結びつくことが期待できる。本報ではその取り組みの 概要について述べる。

\section{2. 避難路に面して築造されたブロック塀等の調查の必要性}

避難所は、地震などの災害の発生時に周辺住民が身を寄せる場と なる重要な施設であり、直に活用されることになる学校などの建築 物の安全性は無論のこと、避難の際のアプローチとなる避難所周辺

*1 Assoc. Prof., Tohoku Institute of Technology, Department of Architecture, Dr. Eng. 
の道路の安全性も確保されている必要がある。しかしながら、現実 には、多数のブロック塀等が周辺の道路に面して築造されており、 それらの中には安全性が疑われるものもある。2003 年宮城県北部連

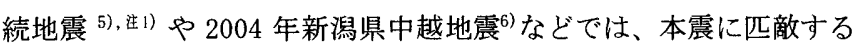
ほどの強い余震が頻発し、余震でもブロック塀等が倒壊している。 それらの点を考えれば 地震災害時の避難路ともなる避難所周辺の 道路の安全性を確保することが急務であり、道路に面するブロック 塀等の状態の確認と共に、倒壊の危険性が疑われる塀については、 積極的に排除してゆくことが必要となる。ただし、ブロック塀等は 個人の所有物であることから、たとえ明確に危険性が認められるも のであっても、撤去の判断は所有者個人に委效れている。また、 行政機関としても、法律上留保されている強制力の行使は、現実に は困難であり、時間と労力をかけながら、所有者に対して粘り強く 説得を続けているのが実状である。

\section{3. 仙台市調查の概要}

仙台市調查は「指定避難路等実態調査」として、1996 年から 2003 年までの 8 年間にわたって実施された。これは同市が指定した避難 所（小·中·高等学校、緑地、公園、運動場など）を中心として、半 径 $500 \mathrm{~m}$ の区域（以後、この区域内の道路を「避難路」と表記）を設 定し、この範囲に含まれる道路に面したブロック塀等について実施 したものである。

この調查では調查対象となった塀について、目視による外観検査 を行ない、その結果をもとに、塀の状態を良好なものから順に A らEまでのランク付けを行なうことで分類している。また、それぞ れには次のように解釈が付されている。

$\mathrm{A} 1$ : 特に問題となる点は見受けられない塀

$\mathrm{A} 2$ : 特に問題となる点は見受けられないが、注意すべき事項があ る塀

B ：注意すべき塀

C ：注意すべき塀であり、外観調査よりもより詳細な調查が望ま しい塀

D ：改修等が望ましい塀

E ：危険な状態にあり、除去が望ましい塀

仙台市が調査の中で実施した外観検查のうち、ブロック塀を対象 としたものは、道路側からの目視検查によって捉えることが可能な 事項を主体として、大略次のように構成されている。

1)塀の種類や規模の把握

2) 建築基準法（施行令第 62 条の 8）規定項目の遵守状況の確認

3) 建築基準法規定外の事項（透かしブロックの状況など）

4）その他（経年劣化の状態、土圧の作用、併設の擁壁の状況など）

他方、外観検查であることから、配筋状態、末端や継手の処理状 態など、壁体内部の鉄筋に関する事項については捉えることができ ない。

調查の現場では、検査の終了直後に、結果の概要を記したカード （外見上の問題点の有無を告知する程度の簡易なもの）を塀の所有 者や占有者に交付し、収集されたデータは、その後、業務委託を受 けた専門業者(一級建築士などの照查技術者)による予備的な評価、 および行政側の担当技師による検討などの過程を経て、総合評価と して、個々の塀にランク付けがなされるようになっている。
総合評価は行政の担当部署において実施されており、その詳細に ついては明らかにされていないが、前段の委託業者による技術的な 評価や検討の結果について、行政的な立場から再精查しているもの と思われる。

総合評価によって低ランクとなった塀の所有者に対しては、その 後、程度に応じて、文書や訪問などにより、個別に改修や除去に向 けた指導を行なうことになっている。従って、この外観検查は、ブ ロック塀等の所有者に対して行政側からの指導を行なうための基礎 的資料を得るために計画・実施されたという特質を持っている。

評価の段階を経る過程での様々な判断の組み合わせが、最終的な 総合評価やランク付けに結びついているため、各ランクの塀の内容 を一義的に示すことはできないが、状態の悪いD・Eの各ランクの塀 としては、例えば、次のようなものが挙げられる。

・Dランク：壁体に傾斜はないが、ひび割れや目地分かれが認めら れている。高さや厚みに問題はないが、控壁が不足し ており、透かしブロックの関係で、既定の配筋が困難 な部分もある。庭土などによる土圧はかかっていなか ったが、調查の時点で危険性なしと判断するには到ら なかった。

・Eランク：Dランクの内容に加えて、壁体に甚だしいひび割れが 認められている。また、調查の時点で危険性なしとは 判断できなかった。

仙台市より提供を受けることができたのは、243 箇所の指定避難 所の周辺について調查された 29,517 件のブロック塀等についての 資料であり、各塀についてのランクに関する情報が含まれていた(以 後、これらを総称して「提供データ」と表記）。また、避難所ごと のブロック塀等の調查数には、大きな相違（最小 1 件、最大 703 件） があった。これは調查区域内におけるブロック塀等の存在数の多少 を反映したものである。

\section{4. データの前処理}

提供データのうち、最も重要な項目は、避難所ごとにまとめられ たAから Eまでのランクに属する塀の件数である。それは倒壊危険 性の程度を表わすものと解釈でき、結果として、AやBに分類され た塀の割合が多い避難路の危険度は低く、DやEのランクに分類さ れ、改修や撤去などが必要な塀（以後、便宜上「不良ブロック塀等」 と表記）の割合が多い避難路の危険度は高いと解积できることにな る。所有者個人に対する行政指導を行なう上では、EランクやD ンクのように、倒壊危険性の程度の高いものから進めてゆくことが 必要であるため、このように細分類する意義があるが、例えば、危 険度の低い避難路を「良」、危険度の高い避難路を「不良」という ように、二事象に集約するだけでも充分な場合がある（以後、「二 事象化」と表記）。実際、2002 年に仙台市調査のシステムを準用し て、小学校のスクールゾーン内にあるブロック塀等の実態調査を実 施した宮城県（土木部）、および県内の市町村では、その後の行政 指導の際に、BランクとCランクの間を境として二事象化し、C $\mathrm{D} \cdot \mathrm{E}$ ランクの塀を「要指導の塀」として行政指導（塀の撤去に向け た指導）を行なった実績がある。

本報では、同様に二事象化を行なった上で検討を進めるが、良・ 不良の二事象に分けるための境界は、宮城県などで採用した実績か 
ら、B・Cランク間に置くことを基本とし、さらに独自の精査(後述) を加えて分析を進めることとした。その際の特性值として用いる不 良率は、「不良」の範疇に含まれる塀の数を当該避難路の塀の調查 数で除した值として、式(1)のように表わすことができる。

$$
p_{i}=\frac{x_{i}}{n_{i}}
$$

$p_{i}:$ 避難所ごとの不良率

$x_{i}:$ 避難所ごとのブロック塀等の不良数

$n_{i}:$ 避難所ごとのブロック塀等の調查数

\section{5. 避難所ごとの避難路の状態評価}

\section{5-1 不良率による評価}

不良率 $p_{i}$ は避難所ごとに容易に求めることができるため、各避難 所について避難路の状龍を評価するにあたり、 $\boldsymbol{p}$ の のを特性値とし て用いることも考えられる。しかし、仙台市調查では、各避難所の 調查数 $n i$ に大きな違いが出ているため、それは望ましくない。また、 特定の不良率の值をもって二事象化するとすれば、その值を境界值 と定める客観的な根拠が得られにくい。そのため、本報においては、 パラメトリックモデルとして確率分布を用い、統計的検定の考え方 を応用しながら評価を行なうこととした。

\section{5-2 二項確率に基づく評価}

ブロック塀等の不良数は、離散量のデータ（計数値）であり、本 分析では不良率を基本的な特性值としていることから、確率分布と しては、二項分布を採用することとなる。避難所の周囲から独立に サンプルサイズ（調査数）nのサンプルを取った時、その中に含ま れる不良ブロック塀等の数 $x$ は確率変数と見な寸ことができ、不良 ブロック塀等が $x$ 件含まれる確率（以後、「二項確率」と表記） $P i$ は、式(2)として表わすことができる。

$$
P_{i}={ }_{n} C_{x} P^{x}(1-P)^{n-x} \quad(x=0,1,2, \cdots, n)
$$

ここに、Pは全体の不良率（母不良率）、 $n C x$ は組み合わせの総数 であり、式(3)となる。

$$
{ }_{n} C_{x}=\frac{n !}{(n-x) ! x !}
$$

仮に、任意の複数の避難路におけるブロック塀等の不良率が見挂 けの上で同值であったとしても、調査数が大きく異なる場合には、 その值をもって、避難路の状態を同等なものとして捉えることには 問題がある。しかし、上記により、不良数出現の確率を求めれば、 その值の大きさより、同一不良率となった避難路間についても差別 化が行なえ、より合理的に避難路の状態を評価することが可能とな る。ただし、現実には、不良率が非常に高い值や低い值を示す避難 路の数が多くなる場合も考えられ、結果として、二項確率の計算値 が $0 \%(0.00)$ である避難路が多数現われる可能性がある。それら について、さらに差別化を図るには、客観的尺度として、「標準測 度」の利用が考えられる。

\section{5-3 眎準測度に基つくく評価}

標準測度 $u$ は正規偏差とも呼ばれるもので、一般に式(4)のように
表わされる。

$$
u=\frac{x-\mu}{\sigma}
$$

ここに

$$
\begin{aligned}
& u: \text { 標準測度 } \\
& \mu: \text { 確率変数 } x \text { の母平均 } \\
& \sigma: \text { 確率変数 } x \text { の母標準偏差 }
\end{aligned}
$$

二項分布の場合、確率変数 $x$ の母平均と母標準偏差の期待值は、 それぞれ式(5)、(6)のように表わされるが、不良率は二項分布の確 率変数をサンプル数で除したものであるため、それぞれは式 (7)、(8) のようになる。従って、式(4)の $\mu$ と $\sigma$ には、それぞれ、式(7) と式 （8）の值を用いることになる。

$$
\begin{aligned}
& E(x)=n P \\
& D(x)=\sqrt{n P(1-P)} \\
& E(p)=P \\
& \cdot D(p)=\sqrt{\frac{P(1-P)}{n}}
\end{aligned}
$$

式 (4) では、分母に標準偏差が配されていることから、標準測度 $u$ の值として通常現われる数値は、 -3 から+3であり、その範囲を超 える場合は、二項確率がほぼ $0 \%$ （0.00末満）となることがわかる。 このことは、二項確率と標準測度の值を勘案すれば、任意の避難路 の状態を、市域の一般的な避難路の状態との比較の上で評価できる ことを示唆している。

統計学において、統計的検定の手法として採用されている基本的 な考え方によれば、 $5 \%(0.05)$ と $1 \%(0.01)$ の出現確率に有意水 淮を置くことが一般的とされている。それを踏襲すると、各避難路 について不良数の出現確率 (二項確率) を求めた場合、その值が $5 \%$ （0.05）または 1\%（0.01）よりも小さな避難路は、出現確率が $5 \%$ を超えるような避難路との比較の上で、「不良ブロック塀等が非常 に少ない」、若しくは「不良ブロック塀等が非常に多い」と判断で きることになり、それぞれは、避難路の状態が「明確に良好」、「明 確に劣悪」という解釈にもつながる。

また、例えば、不良ブロック塀等が非常に多く存在する避難路の 数が多く、結果として、同様の確率の值（例えば $0 \%$ ）が多数現わ れたような場合には、標準測度の值の大きさをもとに、避難路の状 態の程度（劣悪さの程度）を推察することができる。

本報においても、同様の判断基隻を準用し、統計的検定の手法を 応用することを通して、避難路の状態についての考察を行なう。

\section{6. 分析結果}

\section{6-1 二事象化}

仙台市調查は 8 年間にわたって実施されたが、データには年度に よって、ランクの判断基準に多少の相違が生じていた様子が認めら れている注2)。また、一連の調査の初年度である 1996 年の調查では、 システムが未確立であったため、ランクが 1997 年以降とは異なり、 


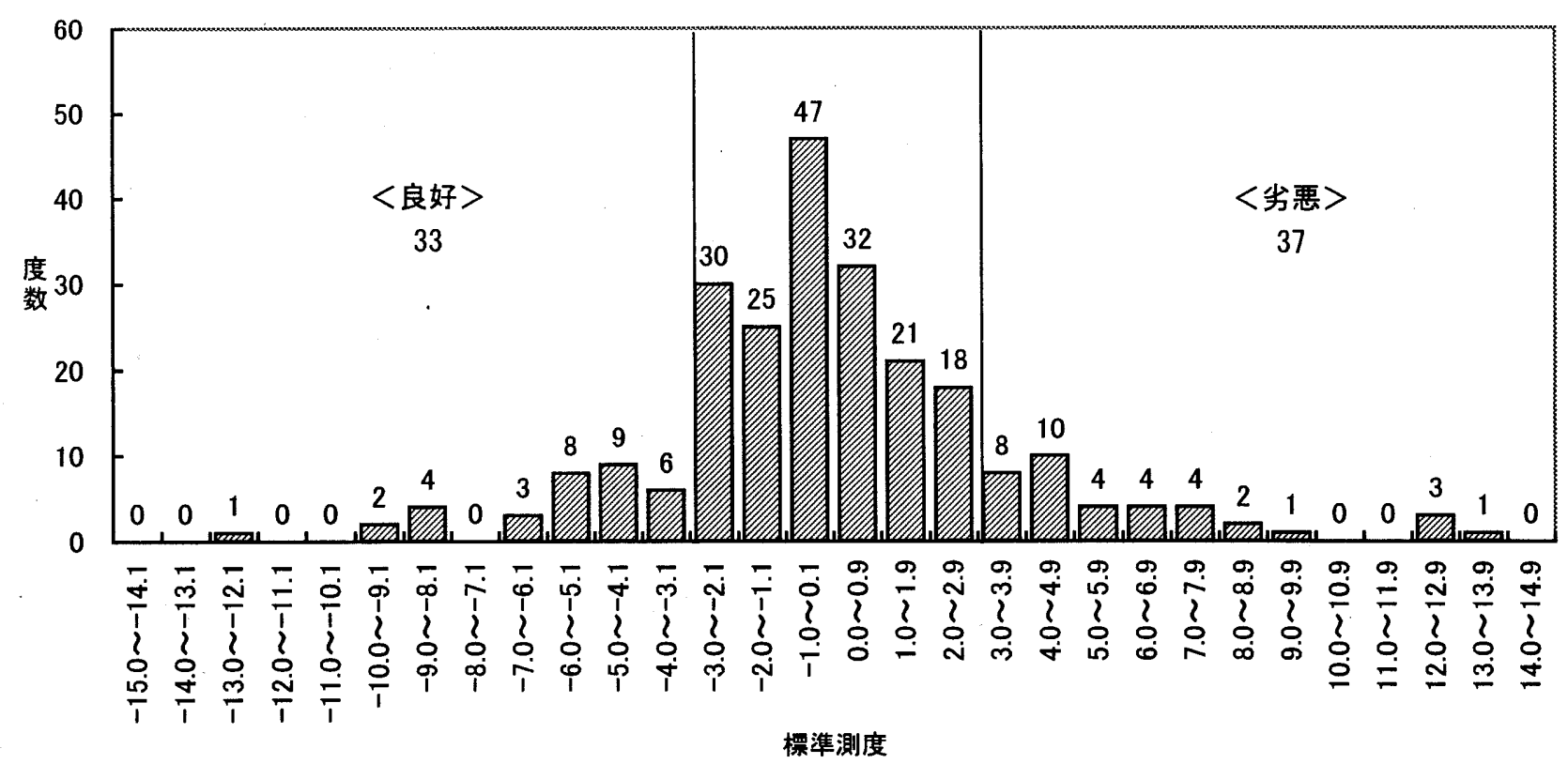

図 1 避難所における標準測度計算值の分布

$\mathrm{A} \cdot \mathrm{B} \cdot \mathrm{C}$ の 3 ランクのみからなる設定となっていた。それらのごと から、二事象化にあたっては、「良」・「不良」に分ける境界の位置 を提供データのランク上に固定せず、提供データのランクを参考に、 各年度について独自に再精查を行なった上で、境界の位置を調整す ることとした。具体的には、過去（1980 年）に仙台市によって実施 された「スクールゾーン内のブロック塀等の実態調査」 ${ }^{2)}$ から推察さ れた母不良率の值と、2002 年に宮城県によって行われた同一調查 ${ }^{4)}$ から推察された母不良率の值が、共に「30\%程度」と得られていたこ とから、本報では仙台市調查における各年度のランクの占有状況を 勘案の上、母不良率が $30 \%$ 程度の值から極端に離れることのない上 うなランク間の位置を、年度ごとの二事象化の境界として設定した。

また、初年度である 1996 年の調査の分については、当時のラン ク設定の定義より、Cランクの塀が「不良」に相当するものと判断 した。

その結果、29,517 件のブロック塀等のサンプルに対し、「不良」 の範疇に属するブロック塀等は 7,626 件となり、全体の不良率（母 不良率)は 0.258 (25.8\%) と得られた。

\section{6-2 二項確率}

二項確率 0.01 の值を下回った避難路は 104 䉂所確認された。その うち、不良側に外れた避難路は 46 箇所あり、それらは「不良ブロッ ク塀等が非常に多い」問題のある避難路と解釈できる。

\section{6-3 標準測度}

全避難路について標準測度を求め、ヒストグラムにまとめたもの を図 1 に示す。図には標準測度士3 の範囲を併せ示した。分布はほ ぼ左右対称の山形の形状を呈しているが、裾野の広がりが大きく、 標準測度は土3 の範囲を大きく超えて、 \pm 13 程度までの值を示して いる。標準測度士3 の範囲には $173(71 \%)$ の避難路が含まれ、同範 囲を外れた避難路は (-) 側 (良好側) に $33(12 \%) 、(+)$ 側 (劣悪側) に $37(15 \%)$ であった。市域の指定避難所のうち、15\%は避難路に おける不良ブロック塀等の存在状態が、他所に比べて顕著であると 解釈できる。

\section{6-4 避難路の状態評価}

表 1 に幾つかの避難所について、避難路の状態判定を行なった結 果の例を示す。これは仙台市青葉区内の避難路について、不良率、 標準測度、二項確率を求め、それらの值を勘案の上、次の二つに分 類・整理したものである。

(1)不良ブロック塀等が他所と比較して非常に多く存在しており、大 規模な地震の発生の際には、道路に面しているブロック塀等の倒 壊によって、避難民が危険に曝されたり、避難が困難になったり する可能性が高いと考えられることから、「避難路に問題あり」

とされる避難所（以後、便宜上「X避難所」と表記）

(2)不良ブロック塀等が他所と比較して非常に少なく、道路に面して いるブロック塀等の倒壊による通行障害の発生や、避難民が危険 に曝される可能性は少ないと考えられることから、「避難路に問 題なし」とされる避難所（以後、便宜上「Y避難所」と表記）

同表の No. 欗は、避難路の状態の良くないもの（X避難所）、あ

表 1 避難路の状態評価結果（例）

〈青葉区 X避難所〉

\begin{tabular}{|c|l|c|c|c|c|c|}
\hline No. & 避難所名 & 不良数 & 調查数 & 不良率 & $\begin{array}{c}\text { 標準 } \\
\text { 測度 }\end{array}$ & $\begin{array}{c}\text { 二項 } \\
\text { 確率 }\end{array}$ \\
\hline 1 & DNH 公園 1 & 94 & 170 & 0.55 & 8.8 & 0.000 \\
\hline 2 & DN 高等学校 & 21 & 39 & 0.54 & 4.0 & 0.000 \\
\hline 3 & KSD 小学校 & 67 & 179 & 0.37 & 3.5 & 0.000 \\
\hline 4 & ARM 小学校 & 66 & 180 & 0.37 & 3.3 & 0.000 \\
\hline 5 & DNH 公園 2 & 191 & 640 & 0.30 & 2.3 & 0.003 \\
\hline
\end{tabular}

〈青葉区 Y避難所〉

\begin{tabular}{|c|l|c|c|c|c|c|}
\hline 1 & HRS 中学校 & 9 & 148 & 0.06 & -5.5 & 0.000 \\
\hline 2 & KIG 小学校 & 37 & 297 & 0.12 & -5.3 & 0.000 \\
\hline 3 & KWD 小学校 & 67 & 425 & 0.16 & -4.7 & 0.000 \\
\hline 4 & KRU 小学校 & 7 & 99 & 0.07 & -4.2 & 0.000 \\
\hline 5 & SNJ 中学校 & 13 & 131 & 0.10 & -4.1 & 0.000 \\
\hline
\end{tabular}

※避難所名には固有名詞に代えて略号を使用 
るいは良いもの（Y避難所）の順位を表わしており、X避難所の場 合、それは地震災害の発生時に、避難所一向かうために通る避難路 の危険度の順位に相当するものと解釈できる。

この順位は、実際には、二項確率と標準測度によって決まってく る值であり、同表からは、不良率の大きさの順番とは必ずしも一致 していない様子が読み取れる。例えば、Y避難所の No.1 (HRS 中学 校）と No. 4 (KRU 小学校) の不良率は、それぞれ「0.06」、「0.07」 と、ほぼ同様の值を示しているが、順位には開きがある。これは同 じ不良率であっても、調查数が異なっていることによる「重みづけ」 の効果が評価に組み入れられていることの表われである。

また、この順位はX避難所についてみれば、行政指導などにおけ る優先度に相当するもの、と解釈することもできる。

\section{7. 地域的な検討}

\section{7-1 避難所ごとの検討}

二項確率の計算值をもとに、二項確率 $0.01 （ 1 \%)$ 以下の避難路 を選別し、仙台市域の地図上に表示したものを図 2 に示す。図中の 濃い○印はX 避難所、薄い○印はY避難所を表わしている。円の大 きさは、仙台市調査における各避難所の調査の範囲(直径 $1 \mathrm{~km}$ )を表 わしている。図より次のことがわかる。

(1) X避難所は、中心市街地周辺、および北部と南部に多く認められ ている。

(2)Y避難所は、市街地から離れた位置に多く認められる。

(3)Y避難所は、市街地中心から見て、X避難所の外側に位置してい る様子が認められる。

(4) Y 避難所には、郊外地域に散在するように分布している様子が認

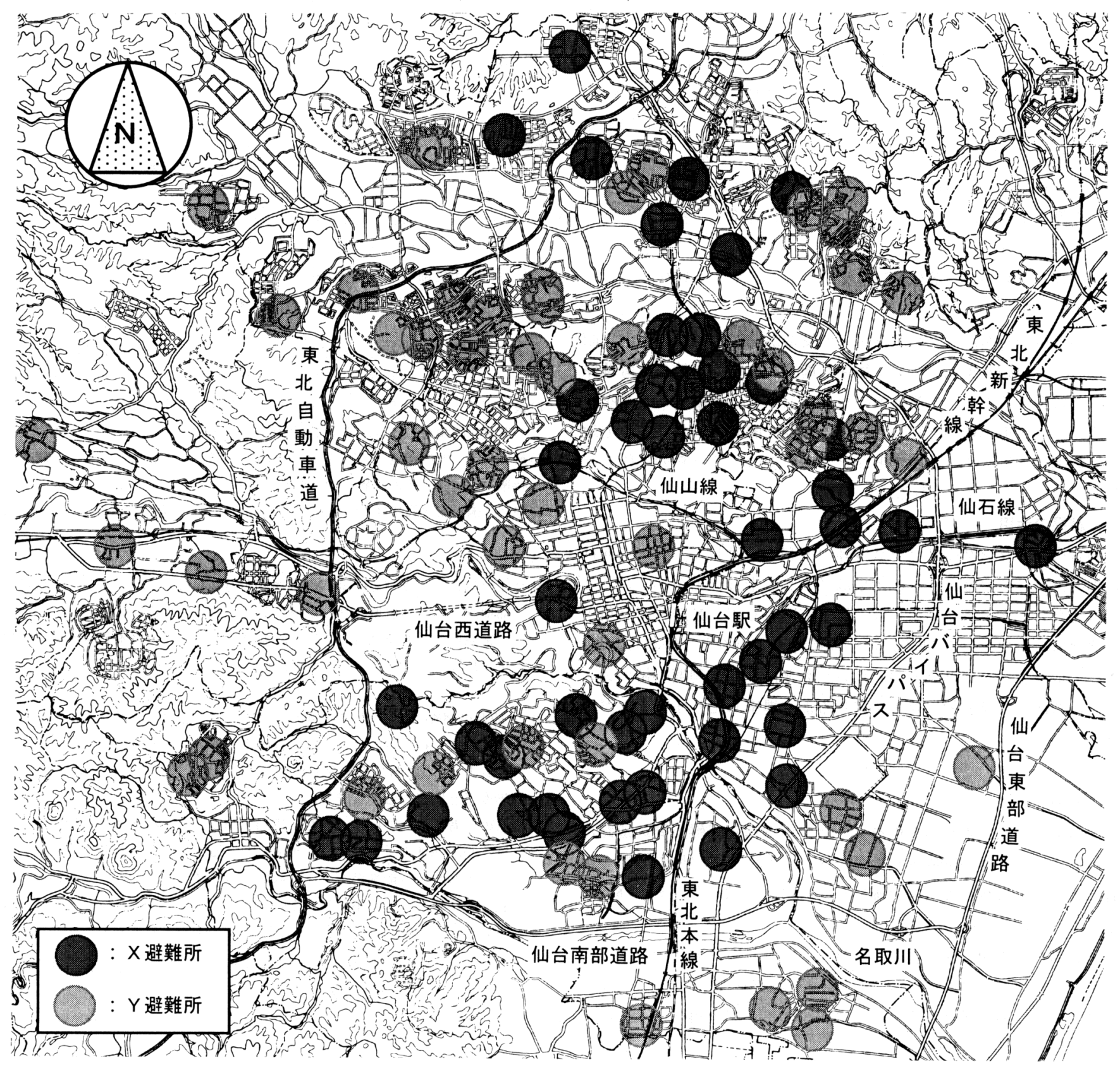

図 $2 \mathrm{X}$ 避難所と $\mathrm{Y}$ 避難所の分布 ${ }^{7)}$ 
められる。

\section{7-2 X・Y 避難所の位置的な特徵}

$\mathrm{X}$ 避難所とY 避難所の位置関倸には、次のように仙台市域の特徵 と対応して解釈できる部分がある。

a. X避難所が中心市街地周辺に環状に認められている点については、 昭和 30 年代から 40 年代にかけて居住が始まった古い住宅地域と 位置関係が符合している。

b. 中心市街地の周辺に環状に存在するX避難所のうち、市街に近い 北方に特に多く認められている地域は、昭和 30 年代後半から、40 年代にかけて造成が行なわれた住宅団地の位置と符合している。

c. X避難所が認められている「北部」と「南部」も、昭和 30 年代 から 40 年代にかけて居住が始まった古い住宅地域である。

d. Y 避難所が X 避難所の外側に位置している点については、住宅地 域の開発が、昭和 50 年代以降に郊外一桩大していった状況と符合 する。

e. 郊外に散在しているY避難所は、昭和 50 年代から平成にかけて開 発された、仙台市域でも比較的新しい住宅地域に位置している。 ブロック塀は昭和 30 年代から普及し始め、昭和 53 年の宮城県沖 地震で耐震性の問題が注目されるようになるまでの間に、夥しい数 が築造された。直接の被害を受けた仙台市内では、その後、行政側 からの働きかけもあって、ブロック塀等の新規筑造の勢いが衰えた ものと考えられるが、昭和 30 年代から 50 年代にかけて築造された 古いブロック塀等が、改修や建替えのされないままに存在し続けて いる実態がある。

$\mathrm{X}$ 避難所の分布が（ブロック塀等の策造が盛んに行なわれた）昭 和 30 年代から 50 年代にかけて居住が進んだ古い住宅地の位置関係 とほぼ符合すること、Y避難所の分布が（ブロック塀等の築造を抑 制する方向人進み始めた) 昭和 50 年代以降に開発された新興住宅地 の位置関係とほぼ符合することなどについては、それらの実態を反 映しているものと考えられる。

\section{7-3 結果の活用}

仙台市は $\mathrm{E}$ ランクのブロック塀等の所有者に対して、撤去に向け た指導を続けているが、その効果は必ずしも十分に上がっていると は言えない。本分析結果からは、仙台市に対して、X避難所が集中 する地域を対象として、重点的に行政指導を進めるよう提案したり、 本報で取り上げた標隻測度の考え方をもとに、標準測度の值の大き いX避難所から優先的に対策を講じるよう提案したりすることがで きる。

\section{8. まとめ}

本報では、仙台市から提供を受けた、市内指定避難所周辺道路に おけるブロック塀等実態調查のデータをもとに、危険性の判定を視 野に入れた、避難路の状態評価について検討を試みた。その経過を まとめると以下のようになる。

1) 仙台市が実態調查結果をもとに付した、ブロック塀等の危険度の ランクをもとに、独自に個々のブロック塀等を良・不良の 2 タイプ に分類し、避難所ごとにブロック塀等の不良率を得た。全体の不 良率は $0.258(25.8 \%)$ であった。

2)二項分布の性質から、不良ブロック塀等の出現確率と標準測度を 求め、それらの值をもとに、「避難路に問題あり」とされる避難
所を選別した。実際には、二項確率 0.01 を境界値として、46 䇢 所について該当する避難所を選定し、さらに標準測度の值から避 難路としての問題の程度を評価した。

3）「避難路に問題あり」とされる避難所の位置関係は、仙台市内の 住宅地の開発事情と符合している様子が窥え、昭和 30 年代から 50 年代にかけて開発された古い住宅地に「避難路に問題あり」と される避難所が多く、昭和 50 年代以降に開発された比較的新しい 住宅地に少ない様子が認められた。

4) 分析の結果は、行政機関が重点的、あるいは優先的に行政指導を 行なうべき地域の選定や、ブロック塀等に関する調査のための、 重点地域の事前選定などに応用することができる。

\section{謝辞}

本研究は、仙台市から提供を受けた、指定避難所等実態調査のデ 一タをもとに分析を進めたものです。仙台市都市整備局住宅宅地部 住環境整備課には、資料の開示について協力を得ました。記して謝 意を表します。

\section{参考文献}

1) 例えば、仙台都市科学研究会（仙台市企画局内）：宮城県沖地震災害に関 する諸調査の総合的分析と評価、243p、1979 年

2) 例えば、仙台市開発局建築部建築指導課：仙台市スクールゾーン内コンク リートブロック塀等実態調查報告書、139P、1981 年

3) 仙台市都市整備局指導部建築指導課 : 平成 8 年度指定避難路等実態調查報 告書、26p、1997 年.（同様の調查報告書はその後、年度ごとに 2004 年ま で刊行)

4) 最知正芳 : 外観調查による既存コンクリートブロック塀の状態判定の有効 性について、日本建築学会技術報告集、第 21 号、pp. 21-26、2005. 03 .

5) 最知正芳：、2003 年 7 月の宮城県北部の地震における組積造垪および門柱 の倒壊原因調查、日本建築学会技術報告集、第 20 号、pp.7-12、2004. 12.

6) 最知正芳 : 2004 年新潟県中越地震において倒壊した租積造垪および門柱の 特徽について、東北工業大学紀要理工学編、第 26 号、pp. 109-121、2006.03. 7) 地図は国土地理院発行 20 万分の 1 地形図（仙台）に基づいて作成

注

注 1)この地震は気象庁から正式な名称が付与されなかったため、「宮城県北 部地震」、「宮城県北部の地震」など、様々な呼称(通称)が使われた。 「宮城県北部連続地震」とは、宮城県（災害復旧対策本部事務局：2004 年 3 月解散）が採用していた呼称である。

注 2）仙台市調查において、調查年度によって、ランクの判断基準に若干の相 違が生じていた点については、行政側も認めている。これは行政のシス テム上、調查にあたる業者を競争入札によって選定することになるため、 年度ごとに替わる調查業者によって、ランクの判断基準に相違が生じた ものと考えられている。即ち、実際に調査にあたった落札業者の間にお ける判断基準の「ずれ」が、年度におけるランクの判断基準の相違とな って表われた可能性が高い。行政側は落札業者に対して、その都度、調 查実施にあたっての事前教育を行なっていたが、現実には、業者間には 事前教育では埋めきれない判断基準の相違が存在したと考えられる。

[2006年10月 18日原稿受理２007年 2 月19日採用決定］ 